
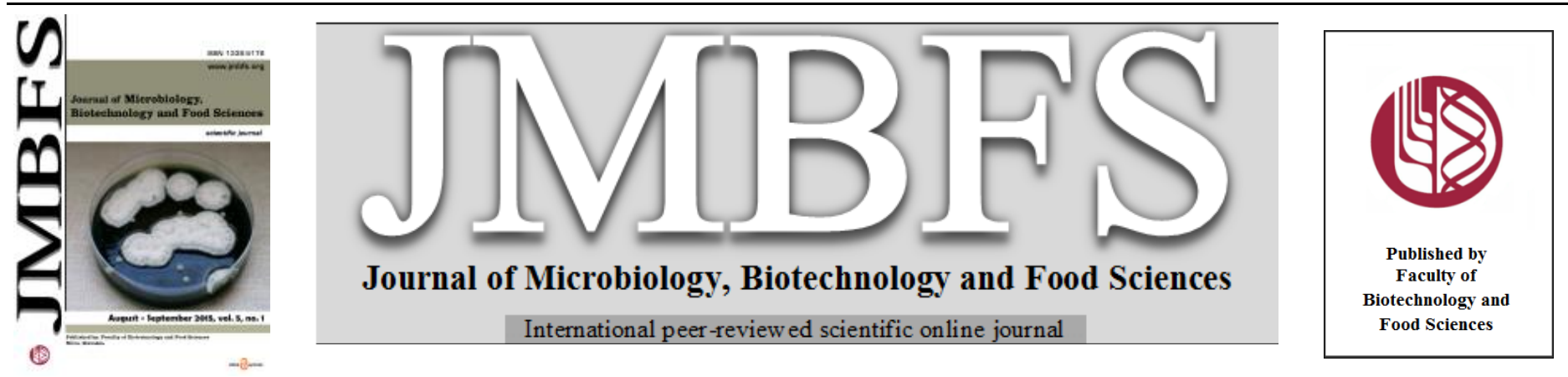

\title{
ISOLATION OF POTENTIAL ANTIMICROBIAL COMPOUNDS FROM SALACIA OBLONGA WALL AND THEIR SYNERGISTIC EFFECT ON HUMAN PATHOGENS
}

\author{
Anjaneyulu Musini ${ }^{\dagger}$,Jayaram Prakash Rao ${ }^{\dagger}$ and Archana Giri*
}

Address(es):

Centre for Biotechnology, Institute of Science and Technology, Jawaharlal Nehru Technological University Hyderabad, India.

*Corresponding author: archanagiriin@yahoo.co.in, anjigen@gmail.com

doi: $10.15414 / j m b f s .2015 .5 .1 .7-11$

\section{ARTICLE INFO}

Received 17. 3. 2015

Revised 7. 4. 2015

Accepted 20. 4. 2015

Published 1. 8. 2015

Regular article

OPEN 2 ACCESS

\begin{abstract}
Salacia oblonga Wall containing vital phytoconstituents viz. mangiferin, salacinol, kotanolol etc has been in use since long in the treatment of cancer, diabetes, inflammation and burn wounds. The antimicrobial activity of $S$. oblonga aerial and root parts has been studied by using ethyl acetate (EtOAc) and methanol $(\mathrm{MeOH})$ solvents. Broad spectrum activity of extracts was prominent against both gram positive and gram negative human pathogens. The lowest minimum inhibitory concentration (MIC) and minimum bactericidal concentration (MBC) value of 0.04 and $0.08 \mathrm{mg} / \mathrm{ml}$ were observed with EtOAc root acidic extract. EtOAc extracts was analyzed by Gas chromatography and mass spectrum (GC-MS) revealing the presence of 79 compounds. The EtOAc extract was further subjected to column chromatography using silica gel and the active fraction showing the highest antibacterial activity were analyzed by liquid chromatography and mass spectrum (LC-MS). The active principles were identified as $\gamma$-sitosterol, $\beta$-Amyrin and Ursa-9(11),12-dien-3$\mathrm{yl}$ acetate. Our study aims at highlighting the potential of $S$. oblonga extracts against various pathogen.
\end{abstract}

Keywords: Salacia oblonga, Antimicrobial activity, Chromatography, $\beta$-Amyrin, $\gamma$-sitosterol

\section{INTRODUCTION}

Plants are an excellent source of new antimicrobial agents as they possess diverse natural molecules in comparison to the chemically synthesized compounds. The compounds derived from natural sources serve as new drugs themselves or templates that could furnish derivatives with modified mechanism of action and fewer side effects (Fernanda et al., 2012). India is one of the mega diverse nations with $11 \%$ of the total world plant biodiversity. Plants are an enormous reservoir of diverse compounds termed as secondary metabolites with proven antimicrobial activity (Rao et al., 2010; Chodisetti et al., 2013; Marasini et al., 2015). These phytochemicals are safe with a long history in traditional medicine and may act as sources for new age antimicrobials with a novel mode of action without being an environmental hazard (Chovanova et al., 2013). The main task is to identify and isolate appropriate plant secondary metabolite from rich pool of plant diversity. Emergence of drug resistance among pathogens and lack of new therapeutics intensify the search for novel antimicrobial agents (Radulovic et al., 2013).

Salacia oblonga Wall has been extensively used in traditional Indian ayurvedic medicine as a liver tonic, anti-inflammatory agent, anodyne amenorrhea, diabetes and treatment of wounds. The root bark extracts are used for itches, asthma, thirst and ear diseases (Li et al., 2008; Chawla et al., 2013). The important phytocostitutents of S.oblonga include salcinol, mangiferin, kotanlol, with proven biological activities viz nephroprotection, antimutagenic, anti-inflammatory and antimicrobial (Ismail et al., 1997; Chawla et al., 2013). The present study is an attempt towards identification of new compounds in the extracts of S. oblonga, responsible for its broad spectrum activity.

\section{MATERIALS AND METHODS}

\section{Chemical and reagents}

The analytical and HPLC grade chemicals and reagents used in the study were procured from Merck and Himedia (India). Amikacin antibiotic was obtained from Sigma-Aldrich (USA).

\section{Preparation of plant extracts}

Salacia oblonga Wall belonging to the family Celastraceae is a woody climber distributed in the Southern regions of India. The plants were collected from Western Ghats, Karnataka, India and authenticated by Dr. N. Siddamallayya,
Research Officer, Regional Research Institute, Bangalore, (India) as S. oblonga Wall (RRCBI 7881). The plant was separated into aerial and root parts, washed thoroughly under running tap water, shade dried and ground to fine powder with the help of an electric blender. The solvents used for the extraction were EtOAc and $\mathrm{MeOH}$ in the presence and absence of $\mathrm{HCl} .100 \mathrm{~g}$ of dried aerial and root powder was used for extraction with the help of a soxhlet apparatus and concentrated using a rotary evaporator (IKA RV 10) at $45^{\circ} \mathrm{C}$. The extracts were stored at $4^{\circ} \mathrm{C}$ for further use.

\section{Microorganisms}

The gram negative bacteria, - Klebsiella pneumonia (MTCC-3384), Enterobacter aerogenes, Enterobacter cloacae, Pseudomonas aeruginosa (MTCC-2295), Escherichia coli (MTCC-7410) and Salmonella typhimurium (MTCC-98) and gram positive bacteria - Staphylococcus aureus (MTCC-7443), Staphylococcus epidermidis, Enterococcus faecalis (MTCC-439), Bacillus subtilis (MTCC-511) and Listeria monocytogenes were used in the present study. Bacterial strains were procured from MTCC, IMTECH, Chandigarh, India, while others were collected as clinical isolates from Global Hospitals, Hyderabad, India. The cultures were maintained on Mueller Hinton Agar slants at $4^{0} \mathrm{C}$. They were revived in Mueller Hinton Broth and cultured at $37^{\circ} \mathrm{C}$ before their use in analyzing the antimicrobial activity.

\section{Antimicrobial assay}

The antimicrobial activity of plant extracts was investigated by the agar well diffusion method (Chovanova et al., 2013). The Mueller-Hinton agar (MHA) was poured into the Petri plates with an inoculum size of $10^{6} \mathrm{cfu}$ (colony forming units $) / \mathrm{ml}$ of bacteria. The wells were made in MHA plates with the help of a borer $(8 \mathrm{~mm})$. The extracts at a concentration of $1 \mathrm{mg} / \mathrm{ml}$ were used for testing the activity. A broad spectrum antibiotic, amikacin at a concentration of $50 \mu \mathrm{g} / \mathrm{ml}$ was used as a positive control, while the solvent \& solvent with $\mathrm{HCl}$ acted as negative controls. The extracts at neutral (7.0) and acidic $\mathrm{pH}$ (5.5) were also analyzed for their activity. The plates were then incubated overnight at $37^{\circ} \mathrm{C}$ to allow bacterial growth. After incubation, the zones of inhibition around each well (including the well diameter) were measured and tabulated for the test organisms. All the experiments were performed in triplicate. 
Minimum inhibitory concentration (MIC) and minimum bactericidal concentration (MBC)

The minimum inhibitory concentration (MIC) was determined by the broth dilution method (Chattopadhyay et al., 1998). Twofold serial dilutions of the crude extracts, with appropriate antibiotic (Amikacin $\mathrm{mg} / \mathrm{ml}$ ) as +ve control were prepared in Mueller-Hinton broth. A direct suspension of microorganisms was prepared in saline from a $24 \mathrm{~h}$ old suspension of Mueller-Hinton broth. The suspension turbidity was adjusted to match $0.5 \mathrm{McFarland}$ standard which corresponds to $2.4 \times 10^{8} \mathrm{cfu} / \mathrm{ml}$. For broth dilution tests, $0.1 \mathrm{ml}$ of the standardized suspension of bacteria $\left(2.4 \times 10^{8} \mathrm{cfu} / \mathrm{ml}\right)$ was added to each tube at a final concentration of $0.005-5.12 \mathrm{mg} / \mathrm{ml}$, and incubated at $37{ }^{\circ} \mathrm{C}$. MBC was taken as the lowest concentration that did not show any visible growth after two fold dilution with plain $\mathrm{MH}$ broth.

\section{GC-MS analysis}

For GC-MS analysis (Vaughn and Berhow, 2005), the samples were injected into a HP-5MS capillary column (30 m length $\mathrm{x} 250 \mu \mathrm{m}$ dia. $\mathrm{x} 0.25 \mu \mathrm{m}$ film thickness), Agilent Technologies, USA GC-MS model, consisting of $6890 \mathrm{~N}$ Gas Chromatograph coupled with 5,973 insert MSD (Mass Selective Detector). The injector was set at $250^{\circ} \mathrm{C}$ and the detector at $280^{\circ} \mathrm{C}$. The stepped temperature program was as follows: held at $50^{\circ} \mathrm{C}$ for $2 \mathrm{~min}$, then, from 50 to $280^{\circ} \mathrm{C}$ at the rate of $10^{\circ} \mathrm{C} / \mathrm{min}$, held for $5 \mathrm{~min}$. The total run time was of $30 \mathrm{~min}$. The GC-MS interface temperature was at $280^{\circ} \mathrm{C}$. The injection volume was $1 \mu \mathrm{l}$. The solvent delay was 3 min and injected in a split less mode. The MS scan range was from 35-6,000 Da. Compound identification was done by comparing the retention time of the compounds with that of the available spectral data with the NIST library of the corresponding compounds.

\section{Column chromatography}

The column chromatography $(450 \times 30 \mathrm{~mm})$ was carried out by using $60-120$ mesh size silica gel to elute individual components from the $S$. oblonga ethyl acetate root acidic extract, exhibiting maximum antimicrobial activity. EtOAc with constant bed volume and size was maintained. The matrix was equilibrated using hexane $(200 \mathrm{ml})$ and compounds eluted using a mobile phase of hexane and EtOAc. The resulting fractions were collected separately, which were analyzed for the antimicrobial activity. The fractions showing good activity were further subjected to LC-MS analysis (Cao et al., 2013).

\section{LC-MS analysis}

In order to identify the components LC-MS analysis was performed on Acquity BEH-C18 column (50 X 2.1mm) $1.7 \mu \mathrm{m}$ (Waters Corp. Milford, MA, USA) and chromatography was performed using $0.1 \%$ ammonium acetate [(A): $0.1 \%$ $\mathrm{HCOOH}(\mathrm{Aq})] \& 0.1 \%$ acetonitrile [(B): $0.1 \% \mathrm{HCOOH}(\mathrm{ACN})]$ as the mobile phase. Separation was accomplished by stepwise gradients from $\mathrm{T} / \mathrm{B} \%: 0 / 10$,
$15 / 100,2.9 / 100,3 / 10$ and flow rate was adjusted to $0.5 \mathrm{ml} / \mathrm{min}$ with diluent: $\mathrm{ACN}$

\section{Statistical Analysis}

The data obtained from the results was calculated as mean \pm standard deviation The triplicate data was also compared by least significant difference test using Statistical Analysis System (ver.9.1)

\section{RESULTS AND DISCUSSION}

\section{Antimicrobial assay}

In the present study antimicrobial activity of $S$. oblonga wall EtOAc and $\mathrm{MeOH}$ extracts was evaluated against various human pathogens. S. oblonga aerial and root parts in EtOAc demonstrated better antibacterial activity towards all the pathogenic species in comparison to $\mathrm{MeOH}$ (Figure 1\&2). The extracts prepared at acidic $\mathrm{pH}$ exhibited better activity in contrast to the extracts at neutral $\mathrm{pH}$. The zones of inhibition for EtOAc extract ranged from $11.63 \pm 0.58 \mathrm{~mm}$ to $21.67 \pm 0.58 \mathrm{~mm}$, whereas $\mathrm{MeOH}$ extracts displayed zones in the range of $9.43 \pm 0.58 \mathrm{~mm}$ to $14.05 \pm 0.58 \mathrm{~mm}$ (Figure 2). The highest zone of inhibition was observed against $K$. pneumonia P. aeruginosa and S.aureus for EtOAc root acidic extract $(21.67 \pm 0.58 \mathrm{~mm}, 20.87 \pm 0.58 \mathrm{~mm}$ and $20.33 \pm 0.47 \mathrm{~mm})$ followed by root neutral $(20.27 \pm 0.4 \mathrm{~mm}, 18.17 \pm 0.58 \mathrm{~mm}$ and $18.93 \pm 0.4 \mathrm{~mm})$, aerial acidic extracts $(20.23 \pm 0.58 \mathrm{~mm}, 17.37 \pm 0.47 \mathrm{~mm}$ and $17.8 \pm 0.35 \mathrm{~mm})$ and aerial neutral extract have shown maximum growth inhibition against $K$. pneumonia $(19.77 \pm 0.38 \mathrm{~mm})$, P. aeruginosa $(16.17 \pm 0.15 \mathrm{~mm})$ and $S$. typhimurium $(16.63 \pm 0.32 \mathrm{~mm})$. In case of methanol, root neutral extract has shown better activity against $P$. aeruginosa $(14.05 \pm 0.27 \mathrm{~mm})$, S.aureus $(13.37 \pm 0.49 \mathrm{~mm})$ and $S$. typhimurium $(13.28 \pm 0.1 \mathrm{~mm})$ while the other extracts have shown moderate activity against all the pathogens. Among the two solvents (EtOAc \& $\mathrm{MeOH})$ used in the study, EtOAc extracts exhibited pronounced antimicrobial activity towards all the pathogens. Hassan $e$ al (2014) reported that varying antimicrobial activity exhibited by different parts of the plant may be attributed to their respective components, which is in correlation to the results obtained in the present study. EtOAc root extract has shown significant activity against $S$.aureus (gram $+\mathrm{ve}$ ) and $P$. aeruginosa (gram ve), the two main organisms responsible for the spread of nosocomial infections EtOAc root acidic extracts of $S$. oblonga have shown superior and significant antibacterial activity against human pathogens compared to other Salacia species (Deepa et al., 2004; Choudhary et al., 2005). The highly pathogenic and capsulated organisms, K. pneumonia and $P$. aeruginosa associated with high morbidity and mortality (Aloush et al., 2006; Carmeli et al., 1999; Gasink et $a l .$, 2006) were efficiently eliminated by the $S$. oblonga root extracts. In case of methanolic extracts, $K$. pneumonia was found to be the most susceptible organism while, E. cloacae, the most resistant.

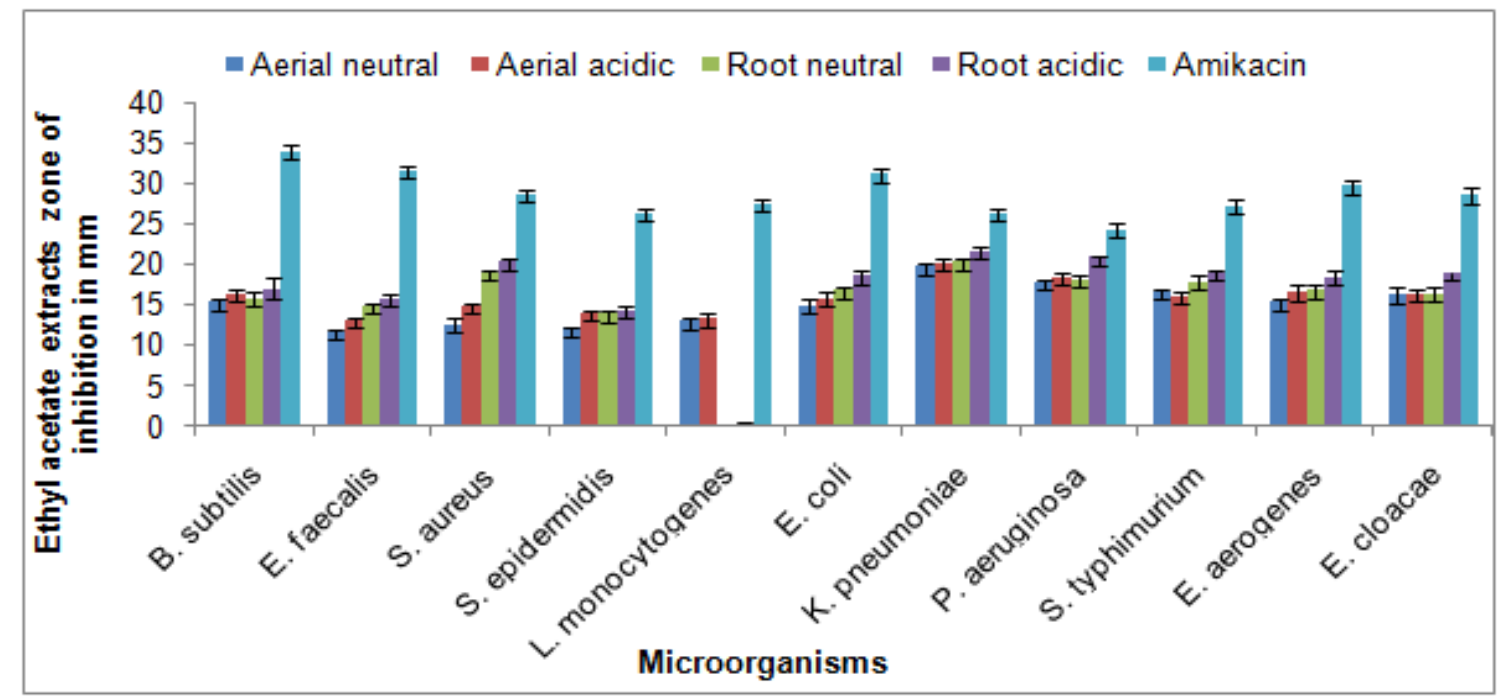

Figure 1 Antimicrobial activity of $S$. oblonga ethyl acetate aerial neutral, aerial acidic, root neutral and root acidic extracts 


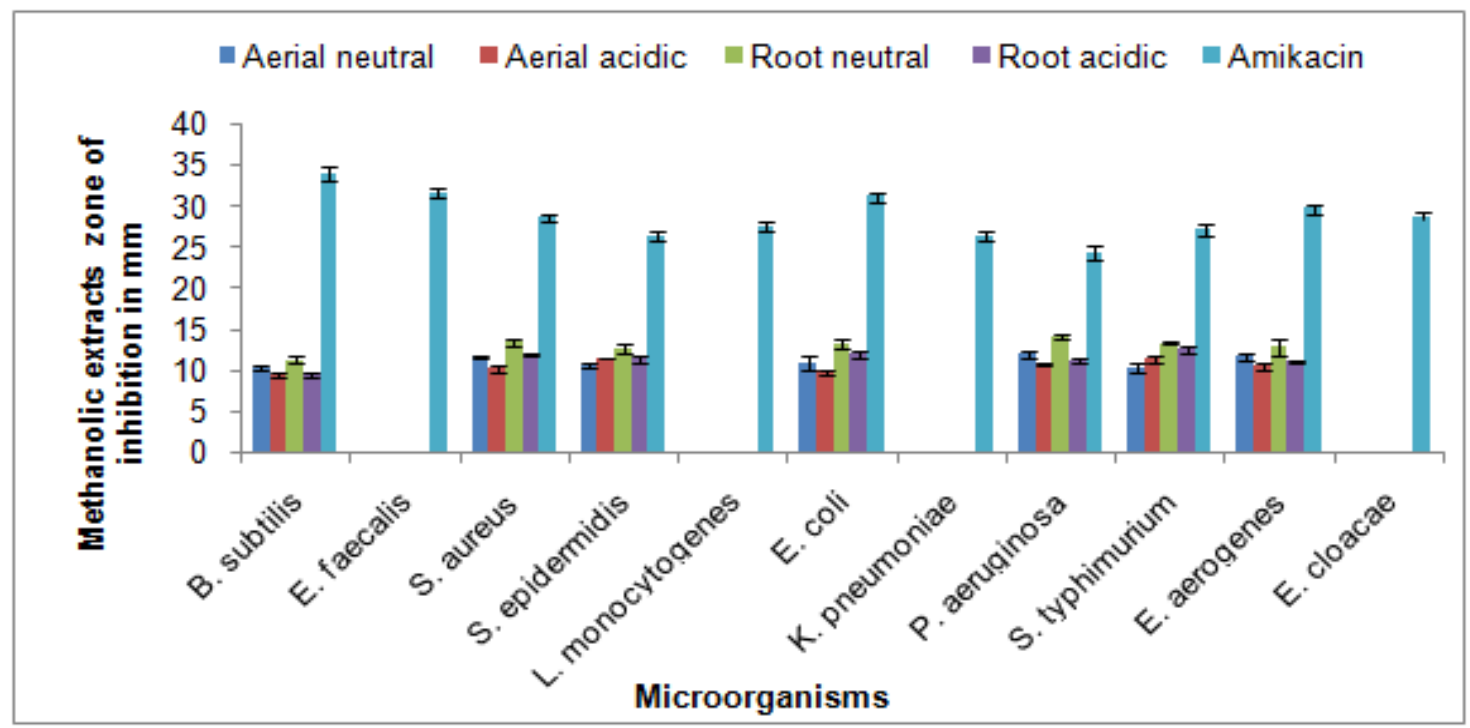

Figure 2 Antimicrobial activity of S. oblonga methanolic aerial neutral, aerial acidic, root neutral and root acidic extracts

Minimum inhibitory concentration (MIC) and Minimum bactericidal concentration (MBC)

MIC and MBC values of the extracts and standards (positive and negative) were obtained by macro broth dilution assay. The MIC and MBC values of $S$. oblonga aerial and root extracts in EtOAc and $\mathrm{MeOH}$ were tested in the range of 0.005 to $5.12 \mathrm{mg} / \mathrm{ml}$. EtOAc extracts exhibited exceptionally low values of MIC ranging from 0.04 to $1.28 \mathrm{mg} / \mathrm{ml} \& \mathrm{MBC}$ values from 0.08 to $2.56 \mathrm{mg} / \mathrm{ml}$ (table 1 ) whereas for $\mathrm{MeOH}$ extracts, MIC $(0.64$ to $2.56 \mathrm{mg} / \mathrm{ml}) \& \mathrm{MBC}(1.28$ to $>5.12$ $\mathrm{mg} / \mathrm{ml}$ ) values were competent (table 2).

Table $1 \mathrm{MIC}$ and MBC values of ethyl acetate extracts against various bacterial strains.

\begin{tabular}{|c|c|c|c|c|c|c|c|c|c|c|}
\hline \multirow{3}{*}{ Pathogenic organism } & \multicolumn{8}{|c|}{ Ethyl acetate extracts $\mathrm{mg} / \mathrm{ml}$} & \multirow{2}{*}{\multicolumn{2}{|c|}{ Amikacin mg/ml }} \\
\hline & \multicolumn{2}{|c|}{$\mathbf{A N}$} & \multicolumn{2}{|c|}{$\mathbf{A A}^{\mathbf{b}}$} & \multicolumn{2}{|c|}{$\mathbf{R N}^{\mathrm{c}}$} & \multicolumn{2}{|c|}{$\mathbf{R A}^{\mathbf{d}}$} & & \\
\hline & MIC & MBC & MIC & MBC & MIC & MBC & MIC & MBC & MIC & MBC \\
\hline B. subtilis & 0.32 & 0.64 & 0.32 & 0.64 & 0.32 & 0.64 & 0.16 & 0.64 & 0.08 & 0.16 \\
\hline E. faecalis & 1.28 & 2.56 & 0.64 & 1.28 & 0.32 & 1.28 & 0.32 & 0.64 & 0.02 & 0.04 \\
\hline S. aureus & 0.64 & 2.56 & 0.64 & 1.28 & 0.16 & 0.32 & 0.08 & 0.16 & 0.08 & 0.16 \\
\hline S. epidermidis & 1.28 & 2.56 & 0.64 & 1.28 & 0.64 & 1.28 & 0.64 & 1.28 & 0.16 & 0.31 \\
\hline L. monocytogenes & 1.28 & 2.56 & 0.64 & 1.28 & $\mathbf{N T}^{\mathrm{e}}$ & NT & NT & NT & 0.08 & 0.16 \\
\hline E. coli & 0.64 & 1.28 & 0.32 & 0.64 & 0.16 & 0.64 & 0.08 & 0.32 & 0.005 & 0.01 \\
\hline K. pneumoniae & 0.08 & 0.16 & 0.08 & 0.16 & 0.08 & 0.16 & 0.08 & 0.16 & 0.08 & 0.32 \\
\hline P. aeruginosa & 0.32 & 0.64 & 0.16 & 0.32 & 0.16 & 0.32 & 0.04 & 0.08 & 0.04 & 0.08 \\
\hline S. typhimurium & 0.16 & 0.64 & 0.16 & 0.32 & 0.16 & 0.32 & 0.08 & 0.32 & 0.08 & 1.25 \\
\hline E. aerogenes & 0.32 & 0.64 & 0.16 & 0.32 & 0.32 & 0.64 & 0.16 & 0.32 & 0.08 & 0.16 \\
\hline E. cloacae & 0.16 & 0.32 & 0.08 & 0.32 & 0.32 & 0.64 & 0.32 & 0.64 & 0.08 & 0.16 \\
\hline
\end{tabular}

$\mathbf{a}=$ aerial neutral, $\mathbf{b}=$ aerial acidic, $\mathbf{c}=$ root neutral, $\mathbf{d}=$ root acidic $\mathbf{e}=$ not tested

The organism $P$. aeruginosa was found to be the most susceptible to EtOAc root acidic extract with low MIC \& MBC values of 0.04 and 0.08 respectively which were comparable to the standard antibiotic amikacin (table 1), followed by $S$. aureus and $K$. pneumoniae with the same MIC and MBC values 0.08 and 0.16 $\mathrm{mg} / \mathrm{ml}$ respectively.

Table 2 MIC and MBC values of methanolic extracts against various bacterial strains.

\begin{tabular}{|c|c|c|c|c|c|c|c|c|c|c|}
\hline \multirow{3}{*}{ Pathogenic organism } & \multicolumn{8}{|c|}{ Methanol extracts mg/ml } & \multirow{2}{*}{\multicolumn{2}{|c|}{ Amikacin mg/m }} \\
\hline & \multicolumn{2}{|c|}{$\mathbf{A N}^{\mathrm{a}}$} & \multicolumn{2}{|c|}{$\mathbf{A A}^{\mathbf{b}}$} & \multicolumn{2}{|c|}{$\mathbf{R N}^{\mathbf{c}}$} & \multicolumn{2}{|c|}{$\mathbf{R A}^{\mathbf{d}}$} & & \\
\hline & MIC & MBC & MIC & MBC & MIC & MBC & MIC & MBC & MIC & MBC \\
\hline B. subtilis & 2.56 & 5.12 & 2.56 & $>5.12$ & 1.28 & 2.56 & 2.56 & $>5.12$ & 0.08 & 0.16 \\
\hline E. faecalis & $\mathbf{N T}^{\mathrm{e}}$ & NT & NT & NT & NT & NT & NT & NT & 0.02 & 0.04 \\
\hline S. aureus & 1.28 & 2.56 & 2.56 & 5.12 & 0.64 & 1.28 & 1.28 & 2.56 & 0.08 & 0.16 \\
\hline S. epidermidis & 1.28 & 5.12 & 1.28 & 2.56 & 0.64 & 1.28 & 1.28 & 2.56 & 0.16 & 0.32 \\
\hline L. monocytogenes & NT & NT & NT & NT & NT & NT & NT & NT & 0.08 & 0.16 \\
\hline E. coli & 1.28 & 5.12 & 2.56 & $>5.12$ & 0.64 & 1.28 & 1.28 & 2.56 & 0.005 & 0.01 \\
\hline K. pneumoniae & NT & NT & NT & NT & NT & NT & NT & NT & 0.08 & 0.32 \\
\hline P. aeruginosa & 1.28 & 2.56 & 1.28 & 2.56 & 0.64 & 1.28 & 1.28 & 2.56 & 0.04 & 0.08 \\
\hline S. typhimurium & 2.56 & 5.12 & 1.28 & 2.56 & 0.64 & 1.28 & 1.28 & 2.56 & 0.08 & 1.28 \\
\hline E. aerogenes & 1.28 & 2.56 & 2.56 & 5.12 & 1.28 & 2.56 & 0.64 & 2.56 & 0.08 & 0.16 \\
\hline E. cloacae & NT & NT & NT & NT & NT & NT & NT & NT & 0.08 & 0.16 \\
\hline
\end{tabular}

$\mathbf{a}=$ aerial neutral, $\mathbf{b}=$ aerial acidic, $\mathbf{c}=$ root neutral, $\mathbf{d}=$ root acidic, $\mathbf{e}=$ not tested 
EtOAc root neutral extract exhibited low MIC and MBC values 0.08 and 0.16 $\mathrm{mg} / \mathrm{ml}$ respectively against $K$. pneumoniae. EtOAc aerial acidic and neutral extract have shown low MIC and MBC values against $K$. pneumoniae and $E$. cloacae and demonstrated moderate MIC \& MBC values against other pathogens (Table 1). In case of methanolic extracts, root neutral extracts have shown more activity towards $E$. coli, S. aureus, $P$. aeruginosa, S. typhimurium and $S$ epidermidis with low MIC and MBC values (Table 2) and moderate activity was found against other pathogens. Among the tested extracts EtOAc root acidic extracts of $S$. oblonga have shown low MIC and MBC values, which were comparable to the standard antibiotic. The results of MIC and MBC have indicated broad spectrum activity, displaying their potential against all the microbes irrespective of them being gram positive or gram negative. Hence it would be beneficial to investigate the active components present in the extracts of $S$. oblonga responsible for good activity leading to the discovery of a novel antimicrobial agent.

\section{GC-MS analysis}

Plants generate varied range of bioactive molecules and in order to characterize these compounds, numerous techniques have been employed, among which the chromatography methods are highly recommended (Dai and Mumper, 2010). Among the different solvents tested for evaluation of antimicrobial activity of $S$. oblonga, ethyl acetate extract had superior activity followed by the methanolic extracts. Hence the GC-MS analysis was carried out to investigate the presence of phytochemicals present in the ethyl acetate extracts of S. oblonga. GC/MS chromatogram of aerial and root parts of EtOAc extracts revealed the presence of 79 compounds (mentioned in supplementary data table 1s and 2s) among which n-Hexadecanoic acid (13.83\%), $\gamma$-Sitosterol (17.24\%), 9-Octadecanoic acid $(14.58 \%), 2,6,10,14,18,22-$ Tetracosahexaene, 2,6,10,15,19,23-Hexamethyl-, (allE)-(21.57\%), 1,3,5-Benzenetriol(19.69\%), N-methoxy-N-methylacetamide (17.38\%), Pentadecanoic acid, 14-methyl-methyl-ester $(20.03 \%)$ and beta amyrin $(3.28 \%)$ were prominent. These compounds are also present in other medicinal plant species and have demonstrated properties like antioxidant, antibacterial, anticancer and anti-inflammatory (Abdel-Raouf et al 2015; Balamurugan et al. 2011; Donga et al., 2010; Brewer et al., 2011).

\section{Silica gel column chromatography}

EtOAc root acidic extract exhibiting maximum antimicrobial activity was subjected to silica gel chromatography. The extract was introduced into the column and partitioned into different fractions with the help of a mobile phase containing hexane and ethyl acetate in the ratio of 95:5ml. Once the fractions were obtained, they were pooled together based on the similar thin laye chromatography (TLC) patterns, the activity of each fraction was checked independently. The obtained fractions were sub fractionated into smaller fractions and evaluated for their activity against the pathogenic bacterial species. Among the tested fractions, one fraction in particular demonstrated excellent activity against all the eleven pathogens. This fraction was analyzed by LC-MS for identification of active components.

\section{Identification of active compounds by LC-MS analysis}

In the LC-MS analysis of $S$. oblonga root acidic extract active fraction demonstrated the presence of three compounds viz $\gamma$-sitosterol (molecular weight: 415.2), $\beta$-amyrin (molecular weight : 425.3) and Ursa-9(11),12-dien-3-yl acetate (molecular weight : 467.3) (Figure 4a-c). Among the three compounds, Ursa-9(11),12-dien-3-yl acetate compound was not detected earlier in the extracts of $S$. oblonga.

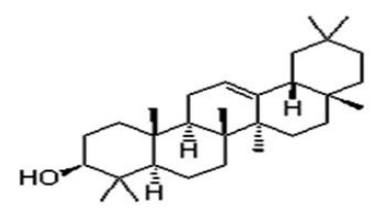

a. Beta amyrin

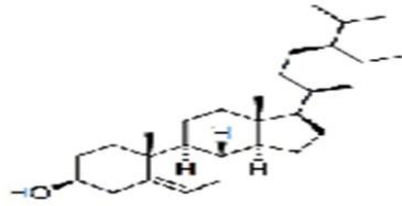

b. Gama sitosterol

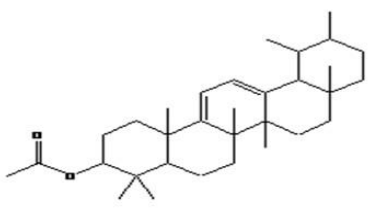

c. Ursa-9(11),12-dien-3-yl acetate

Figure 3 a, b, c Molecular structures of the compounds identified by LC-MS analysis
The presence of $\beta$ amyrin and $\gamma$-sitosterol (triterpenes) in the active fraction associated with antibacterial activity has been reported by Abdel-Raouf et al (2013) in the ethanolic extracts of Laurencia microcladia. Similar findings were reported in Salvia bicolor petroleum ether extracts with high amounts of $\beta$ amyrin exhibiting antimicrobial, antioxidant and anti-inflammatory activities (Ibrahim, 2010). Though the activity of $\gamma$-sitosterol has not been confirmed, its presence in various plant extracts is responsible for antibacterial, antifungal, anticancer, antidiabetic and antiinflammatory activities which has been reported for Lippia nodiflora L (Balamurugan et al., 2011), Manglietia glauc (Zhong-feng and Xia-yan, 2011), pitaya (dragon fruit) peel (Luo et al., 2014) etc. Ursa-9(11),12dien-3-yl acetate, a triterpene, has been reported in Dorstenia arifolia and is thought to be associated with various biological and pharmacological activities viz. antimicrobial, anti-inflammatory, antiviral and cytotoxic activities (Silva et al., 2012; Fingolo et al., 2013). Terpenoids with aldehyde or alcoholic moieties can interact with membrane incorporated proteins by changing their conformation and functionality, thereby causing death of the microbes (Radulovic et al., 2013; Rao et al., 2010). Secondary effects which may further affect the viability of microbial cells include the inhibition of several enzymes caused by leakage of essential ions, loss of turgor pressure and alteration in macromolecular synthesis.

The higher activity of crude extracts $(21.67 \pm 0.58 \mathrm{~mm})$ in comparison to the pure compounds $(17.14 \pm 0.4 \mathrm{~mm})$ is because of the presence of a complete arsenal of compounds in the plant system exhibiting synergism as against the single compound. These multiple compounds exhibit different modes of action on the microbes simultaneously, thereby disabling their elimination mechanisms indirectly reducing any chance of survival. Combination therapy is useful and considerable, particularly in patients with serious infections caused by pathogens associated with drug resistance (Olayinka et al., 2009). With the development of new techniques viz. metabolomics and chemometric data analysis methods, it would be easy to analyze all the modes of action exhibited by the complex herbal preparations (Radulovic et al., 2013).

\section{CONCLUSION}

The broad spectrum activity exhibited by $S$. oblonga root acidic extracts was comparable to the available standard drugs used to treat persistent nosocomial infections. The three compounds isolated from the active fraction obtained after silica gel column chromatography and identified by LC-MS as $\gamma$-sitosterol, $\beta$ amyrin and Ursa-9(11),12-dien-3-yl acetate have been associated with various biological activities. Though $\gamma$-sitosterol and $\beta$-amyrin have been attributed with proven activity, the activity of newly isolated, Ursa-9(11), 12-dien-3-yl acetate has been confirmed for the first time in the present study. Exploitation of the plant products (secondary metabolites) for disease control has advantages in terms of cost, biodegradability and availability. Synergistic broad spectrum activities of the plant extracts can contribute to the discovery of new templates for drug development against the escalating antibiotic resistance shown by the microorganisms.

Acknowledgments: The authors are thankful to the authorities of JNTUH for providing laboratory facilities and for financial support.

Contribution: ${ }^{\dagger}$ Both the authors have contributed equally for the scientific report.

Conflict of Interest: Authors have no conflict of interest.

\section{REFERENCES}

ABDEL-RAOUF, N., AL-ENAZI, NM., AL-HOMAIDAN, A., IBBRAHEEM, IBM., AL-OTHMAN, MR., HATAMLEH, AA. 2015. Antibacterial $\beta$-amyrin isolated from Laurencia misrocladia. Arabian journal of chemistry, 8, 32-37. http://dx.doi.org/10.1016/i.arabic.2013.09.033

ALOUSH, V., NAVON-VENEZIA, S., SEIGMAN-IGRA, Y., CABILI, S., CARMELI, Y. 2006. Multidrug-resistant Pseudomonas aeruginosa: risk factors and clinical impact. Antimicrob. Agents Chemother, 50, 43-48. http://dx.org/10.1128/AAC.50.1.43-48.2006.

BALAMURUGAN, R., DURAIPANDIYAN, V., IGNACIMUTHU, S. 2011. Antidiabetic activity of $\gamma$-sitosterol isolated from Lippia nodiflora L. in streptozotocin induced diabetic rats. Eur J Pharmacol, 667, 410-418. http://dx.org/10.1016/j.ejphar.2011.05.02.

BREWER, MS. 2011. Natural antioxidants: Sources, compounds, mechanism of action and potential applications. Compr Rev Food Sci F, 10, 221-247. http://onlinelibrary.wiley.com/doi/10.1111/j.1541-4337.2011.00156.x/full CAO, X., XU, J., BAI, G., ZHANG, H., LIU, Y., XIANG, J., TANG, Y. 2013. Isolation of anti-tumor compounds from the stem bark of Zanthoxylum ailanthoides Sieb. \& Zucc. by silica gel column and counter-current chromatography. Journal of Chromatography B, 929, 6-10. http://dx.doi.org/10.1016/i.jchromb.2013.04.006. 
CARMELI, Y., TROILlET, N., KARCHMER, AW., SAMORE, MH. 1999. Health and economic outcomes of antibiotic resistant Pseudomonas aeruginosa Arch. Intern. Med. 159, 1127-1132. http://dx.org/10.1001/archinte.159.10.1127. CHATTOPADHYAY, D., MUKHERJEE, T., PAL, P., SAHA, B., BHANDRA, R. 1998. Altered membrane permeability as the basis of bacterial action of methdilazine. Journal of Antimicrobial chemotherapy, 42, 83-86 http://dx.org/10.1093/jac/42.1.83

CHAWLA, A., SINGH, S., SHARMA, AK. 2013. Salacia oblonga Wall: A review on its pharmacognostic, Phytochemical and pharmacological aspects International journal of research in Pharmaceutical and biomedical sciences, 4 , 1215-1228.

CHODISETTI, B., RAO, K., GIRI, A. 2013. Phytochemical analysis of $G$ sylvestre and evaluation of its antimicrobial activity. Nat Prod Res, 27, 583-587. http://dx.org/10.1080/14786419.2012.676548

CHOVANOVA, R., MIKULÁŠOVÁ, M., VAVERKOVÁ, S. 2013. In Vitro Antibacterial and Antibiotic Resistance Modifying Effect of Bioactive Plant Extracts on Methicillin-Resistant Staphylococcus epidermidis. International Journal of Microbiology. http://dx.org/10.1155/2013/760969.

CHOUDHARY, GP., VIJAY KANTH, MS. 2005. Antimicrobial Activity of Root bark of Salacia reticulate. Ancient Science of Life, 1, 4-7.

DAI, J., MUMPER, JM. 2010. Plant Phenolics: Extraction, Analysis and Their Antioxidant and Anticancer Properties. Molecules, 15, 7313 7352.http://dx.doi.org/10.3390/molecules15107313.

DEEPA, MA., BAI, VN. 2004. Antibacterial activity of Salacia beddomei. Fitoterapia, 75, 589 -591. http://dx.org/10.1016/j.fitote.2004.04.011.

DONGA, Y., NAKAGAWA-GOTOA, K., LAIA, CY., MORRISNATSCHKEA, SL., BASTOWB, KF., LEEA, KH. 2010. Antitumor Agents 278 4-Amino-2H-benzo[h]chromen-2-one (ABO) Analogs as Potent In Vitro Anticancer Agents. Bioorg Med Chem Lett, 20, 4085-4087. http://dx.doi.org /10.1016/j.bmcl.2010.05.079.

FERNANDA, MDS., MARIA, GDS., ANTONIO, EMC., CARLOS, HGM., SERGIO, RA., RODRIGO, CSV., MARCIO, LAES., WILSON, RC. 2012 Evaluation of antimicrobial activity of extracts of Tibouchina Candolleana (Melastomataceae), isolated compounds and semi synthetic derivatives against endodontic bacteria. Braz J Microbiolo, 43(2), 793-799. http://dx.org/10.1590/S1517-83822012000200045.

FINGOLO, CE., SANTOS, TDS., FILHO, MDMV., KAPLAN, MAC. 2013 Triterpene Esters: Natural products from Dorstenia arifolia (Moraceae) Molecules, 18, 4247-4246. http://dx.org/10.3390/molecules18044247

GASINK, LB., FISHMAN, NO., WEINER, MG., NACHAMKIN, I., BILKER

WB., LAUTENBACH, E. 2006. Fluoroquinolone-resistant Pseudomonas aeruginosa: assessment of risk factors and clinical impact. Am. J. Med., 119 526e19-526e25. http://dx.doi.org/10.1016/j.amjmed.2005.11.029

HASSAN, HM., JIANG, ZH., ASMUSSEN, C., MCDONAL, DE., QIN, W. 2014. Antibacterial activity of northern Ontario medicinal plant extracts. Can. J.Plant Sci, 94, 417-424. http://dx.org/10.4141/cjps2013-258

IBRAHIM, TA. 2012. Chemical Composition and Biological Activity of Extracts from Salvia bicolor Desf. Growing in Egypt Molecules, 17, 11315-11334. http://dx.org/103390/molecule171011315

ISMAIL, TS., GOPALAKRISHNAN, S., BEGUM, VH. 1997. Antiinflammatory activity of Salacia oblonga Wall and Azima tetracantha Lam Journal of Ethnopharmacol, 56, 145-152. http://dx.doi.org/10.1016/S0378 8741(96)01523-1.

LI, Y., HUANG, TH., YAMAHARA, J. 2008. Salacia root, a unique Ayurvedic medicine, meets multiple targets in diabetes and obesity. Life Sci, 82, 1045-1049. http://www.ncbi.nlm.nih.gov/pubmed/18433791

LUO,H., Cai,Y., Peng, Z., Liu, T., Yang, S. 2014. Chemical composition and in vitro evaluation of the cytotoxic and antioxidant activities of supercritical carbon dioxide extracts of pitaya (dragon fruit) peel. Chemistry Central Journal, 8-1. http://dx.doi.org/10.1186/1752-153X-8-1

MARASINI, BP., BARAL, P., PRATIBHA ARYAL, P., GHIMIRE, KR., SANJIV NEUPANE, S., DAHAL, N., ANJANA SINGH, A., GHIMIRE, L., SHRESTHA, K. Evaluation of Antibacterial Activity of Some Traditionally UsedMedicinal Plants against Human Pathogenic Bacteria. BioMed Research International, 265425, 1-6.http://dx.doi.org/10.1155/2015/265425.

OLAYINKA, AA., ANTHONY, JA., ANTHONY, OI. 2009. Synergistic interaction of Helichrysum pedunculatum leaf extracts with antibiotics agains wound infection associated bacteria. Biological research, 42, 327-338 http://dx.doi.org/10.4067/S0716-97602009000300007.

SILVA, M.L., DAVID, JP., SILVA, L.C.R.C., SANTOS, R.A.F., DAVID, J.M. LIMAL, S., PEDRO, S.R., FONTANA, R. 2012. Bioactive oleanane, oupane and ursane triterpene acid derivatives. Molecules , 17, 12197-12205. http//:dx.org/10.3390/molecules171012197

RADULOVIC, NS., BLAGOJEVIC, PD., STOJANOVIC-RADIC, ZZ. STOJANOVIC, NM. 2013. Antimicrobial plant metabolites: structural diversity and mechanism of action. Curr. Med. Chem, 20, 932-952. http//:dx.org/10.2174/0929867311320070008
RAO, K., BHUVANESWARI, CH., NARASU, LM., GIRI, A. 2010 Antibacterial Activity of Alpinia galanga (L) Willd Crude Extracts. Appl Biochem Biotechnol, 162, 871-884. http://dx.doi.org/10.1007/s12010-009-8900 $\underline{9}$.

VAUGHN, SF., BERHOW, MA. 2005. Glucosinolate hydrolysis products from various plant sources: $\mathrm{pH}$ effects, isolation,and purification. Ind Crop and Prod 21, 193-202. http//:dx.org/10.1016/i.indcrop.2004.03.004.

ZHONG-FENG, Z., XIA-YAN, Z. 2011. GC/MS Analysis on Benzene/Alcoho Extractives of Manglietia Glauca Leaves for Biomedicine Engineering, Advanced Materials Research, 213, 475-478. http//:dx.org/10.4028/www.scientific.net/AMR.213.475. 